\begin{tabular}{|l|l|l||}
\hline \multicolumn{2}{|c|}{ PublisherInfo } \\
\hline \hline PublisherName & $:$ & BioMed Central \\
\hline \hline PublisherLocation & $:$ & London \\
\hline \hline PublisherImprintName & $:$ & BioMed Central \\
\hline \hline
\end{tabular}

\title{
Transfusing prior to extubation
}

\begin{tabular}{|l|l|l||}
\hline \multicolumn{2}{|c||}{ ArticleInfo } \\
\hline \hline ArticleID & $:$ & 4309 \\
\hline \hline ArticleDOI & $:$ & $10.1186 /$ ccf-2001-73305 \\
\hline \hline ArticleCitationID & $:$ & 73305 \\
\hline \hline ArticleSequenceNumber & $:$ & 20 \\
\hline \hline ArticleCategory & $:$ & Paper Report \\
\hline \hline ArticleFirstPage & $:$ & 1 \\
\hline \hline ArticleLastPage & $:$ & 3 \\
\hline \hline & & RegistrationDate : 2001-12-4 \\
ArticleHistory & $:$ & Received \\
\hline ArticleCopyright & $:$ 2001-7-17 \\
\hline \hline ArticleGrants & $:$ & OnlineDate \\
\hline \hline ArticleContext & $:$ & 130054-12-4 \\
\hline \hline
\end{tabular}


Aff1 Christiana Care Health Systems, Wilmington, DE, USA

\section{Keywords}

Anemia, artificial respiration, red blood cell transfusion

\section{Context}

It is believed that in ventilated patients, anemia that results in decreased oxygen carrying capacity can slow respiratory recovery. This study compared restrictive and liberal transfusion practices in ventilated patients and studied the duration of ventilation, time to successful extubation (weaning), and complications.

\section{Significant findings}

There were no statistically significant differences in length of ventilation or time to wean between the two groups after adjusting for confounding factors. Multiple organ dysfunction (MOD) score and mortality increased slightly in the liberal strategy group. Also more complications were noted in the liberal strategy group, including pulmonary edema and myocardial infarction.

\section{Comments}

The study was a subgroup of a larger study and there is the possibility of unknown confounding factors. For instance, weaning methods were not uniform. This study suggests that a liberal transfusion policy will not improve respiratory performance in mechanical ventilation. These results are consistent with previous work suggesting that in critically ill patients without coronary artery disease, there is no advantage to a more aggressive transfusion strategy, and that for most ICU patients maintenance of hemoglobin levels $>7 \mathrm{~g} / \mathrm{dl}$ is probably adequate. 


\section{Methods}

Prospective randomized trial of 713 ventilated patients who were part of a larger study (Transfusion Requirements in Critical Care). Patients were randomized to receive transfusions with a hemoglobin concentration of either 7-9 g/dl (restrictive strategy) or 10-12 g/dl (liberal strategy). Confounding variables were forced into a Cox model.

\section{Additional information}

\section{References}

1. Hebert PC, Blajchman MA, Cook DJ, Yetisir E, Wells G, Marshall J, Schweitzer I and the Transfusion Requirements in Critical Care Investigators for the Canadian Critical Care Trials Group : Do blood transfusions improve outcomes relted to mechanical intervention. Chest. 2001, 119: 1850-1857. 